UDC

DOI: $10.17223 / 18572685 / 44 / 11$

\title{
THE STATUS OF GREEK CATHOLIC RUSYNS IN SLOVAKIA DURING WORLD WAR I (ECONOMIC, CULTURAL AND RELIGIOUS ASPECTS)
}

\author{
Ja. Coranič \\ University of Prešov \\ Street of bishop Gojdič 2, 08001 Prešov, Slovak Republic \\ E-mail: jaroslav.coranic@unipo.sk
}

\section{Abstract}

Political, economic, cultural and social development of Greek Catholic Rusyns in Slovakia was greatly influenced by the events of World War I., at the end of the AustroHungarian Empire. The present study is devoted mainly to economic, cultural and religious aspect of that period. The poor economic situation caused the emigration of high number of population to overseas, especially to the USA. This status of one of the poorest parts of Hungary has significantly worsened after the outbreak of the World War I. The north-eastern Slovakia, inhabited mainly by Rusyns, became a place of heavy combat operations for a few months at the turn of 1914-1915. After the final retreat of the front there was desolate landscape remained, marked by military graves. A large part of the population was evacuated from threatened area. Many villages have been partially or completely burned. During the duration of World War I. this population was severely tested also in cultural and religious matters. Several proposals of the Hungarian government meant the visible interference with the Eastern tradition of the Greek Catholic Church. Gradually a number of reforms was forcibly introduced by the state authorities, such as the sacral ceremony reform, the church calendar reform, the script reform (the Cyrillic alphabet removing), the reform of education of the priests in seminaries, the reform of Order of St. Basil the Great. These reforms, however, were refused to accept by the Ruthenian Greek Catholic population. Due to the approaching end of World War I. the Hungarian government did not have enough time to undertake this reforms. Ruthenian Greek Catholic faithful in Czechoslovakia (in the Diocese of Mukachevo and Presov) decided to stay with the old Julian calendar and Cyrillic script after the collapse of Austria-Hungary in 1918. The partial improvement of the status of the Rusyns in Slovakia became after the establishment of the new Czechoslovak 
state in 1918, although many of the hopes and aspirations of this nation were not fulfilled yet.

Keywords: Rusyns in Slovakia, Greek Catholic church on Slovakia, WWI, economic question, cultural-religious question.

\title{
ПОЛОЖЕНИЕ РУСИНСКИХ ГРЕКО- КАТОЛИЧЕСКИХ ВЕРУЮЩИХ В СЛОВАКИИ ВО ВРЕМЯ ПЕРВОЙ МИРОВОЙ ВОЙНЫ (ЭКОНОМИЧЕСКИЙ, КУЛЬТУРНЫЙ И РЕЛИГИОЗНЫЙ АСПЕКТЫ)
}

\author{
Я. Цоранич \\ Прешевский университет \\ 08001, Словацкая республика, г. Прешев, ул. епископа Гойдича, 2 \\ E-mail: jaroslav.coranic@unipo.sk
}

\section{Авторское резюме}

Данное исследование посвящено в основном экономическому, культурному и религиозному аспектам рассматриваемого периода. Неблагополучная экономическая ситуация привела к эмиграции значительной части населения преимущественно в США. Ситуация в одном из самых бедных районов Угорской Республики значительно ухудшилась после начала Первой мировой войны. Северо-восточная область Словакии, где жили русины, стала в течение нескольких месяцев 1914-1915 гг. местом тяжелых боевых действий. После окончательного отступления фронта остались лишь разоренная земля и могилы воинов. Значительная часть населения деревень, находившихся под угрозой, была эвакуирована. Многие деревни были полностью или частично сожжены. Во время Первой мировой войны население испытывало давление со стороны греко-католической церкви. Государственные органы постепенно насильно ввели ряд реформ (например, реформу богослужебных церемоний, церковную реформу календаря и реформу письма (удаление кириллицы и ее замена латиницей)). Русинское греко-католическое население эти реформы отказалось принять. В связи с приближавшимся концом Первой мировой войны угорскому правительству не хватало достаточно времени, чтобы реализовать эти реформы. После распада Австро-Венгрии в 1918 г. русинские верующие решили остаться со старым 
юлианским календарем и кириллицей (в Прешовской и Мукачевской епархии). Частичное улучшение положения русинов в Словакии наступило только после создания нового Чехословацкого государства в 1918 г., хотя многие надежды и желания народа не сбылись до сих пор.

Ключевые слова: русины в Словакии, греко-католическая церковь в Словакии, Первая мировая война, экономический вопрос, культурно-религиозный вопрос.

Economic and financial situation in regions inhabited by Rusyns significantly worsened in the last three decades of $19^{\text {th }}$ century and at the beginning of $20^{\text {th }}$ century. This region had been one of the poorest in the Hungarian Kingdom and it remained basically unchanged. The situation was further complicated by growing population, lack of farmland, and primarily by poorly developed industry unable to provide enough job opportunities. As a result, the end of the $19^{\text {th }}$ century witnessed the emigration boom. Agricultural labourers, servants and small farmers, that is, all those hardly employable in their home country, predominated among the emigrants. Women, children and elderly people generally stayed home. In the beginning, Rusyns migrated to work only within the country, settling mostly in southern parts of the Hungarian Kingdom, in the region of Bacska Nojvodina/ (Magocsi 2007: 61). In the late eighteen seventies the first Rusyn families started to migrate to the USA. It is estimated that roughly 150000 Rusyns left the Hungarian Kingdom by the year 1914, and about half of them came from the Prešov region. (Magocsi 1994: 149).

Rusyn population in the north-east of Slovakia was confronted with very bleak reality in the years 1914-1918, and that was a very difficult social and economic situation. At the turn of the years 1914-1915, the North-east Slovakia, inhabited mainly by Rusyns, became for a few months a scene of heavy battles that broke out on 20 November 1914. Part of the Russian army crossed the Carpathian Pass Ruské sedlo and in a hasty attack seized the four villages Ruské, Vel'ká Pol'ana, Smolník, and Zvala. In the following days, the Russian army succeeded in taking other villages in the Cirocha river valley. Snina was seized on 23 November and Humenné on 24 November.

Only after regrouping of the Austro-Hungarian army, was this Russian offensive halted. In the end, the Russian army withdrew back to the ridges of the Carpathian Mountains after heavy fightings on 2628 November 1914. (Bural' 2010: 11-12). At the same time, however, the Russian army launched an attack in the area of Dukla Pass. On 30 November they took Zborov and on 1 December Bardejov, too. By the 3 December 1914 the Russian army seized one third of all villages 
in Šariš county, 58 villages in Bardejov district, 60 villages in Svidnik district and 7 villages in Giraltovce district (Slepcov 2005: 20).

On 8 December, before the approach of the Austro-Hungarian army, the Russian troops started the unexpected retreat from Bardejov. Even here the front line was moved to the ridges of the Carpathian Mountains. In January 1915 the Russian army fought their way back to Slovak territory for the second time in the pursuit of the Austro-Hungarian army which made a failed counter-offensive attempt. German and Austro-Hungarian armies launched a counter-offensive on 22 January 1915. The Russian troops, however, fended off the attack towards the end of January and then they seized Medzilaborce in a counter-attack through Čertižné a Habura (Kováč 2008: 57). While at the turn of the months November and December 1914 the clashes were rather light, battles in 1915 were mostly heavy artillery and trench fightings.

The turning point came with the break-through the Russian defence line, near the Polish village of Gorlice in early May. The attack of German and Austro-Hungarian troops began on 2 May. The Russian armies were forced to retreat from the Slovak territory fearing the siege. And so on 7 May 1915 the Russian troops left a few last villages in the area of the Łupkov Pass. (Kováč: 58).

After the full retreat of the Russian army, the country was left ravaged and strewn with soldiers graves. A large part of the population was evacuated from the threatened villages. Yet many villages were partially or completely burnt down. Multiple damage was caused to the property of inhabitants not only by fighting alone, but also by retreat and movement of all the front line armies, and tactical strategies of the military command. It was mainly the Austro-Hungarian army which was forced to ravage those villages in the front line that could possibly serve as a shelter for enemy troops.

This way around twenty villages "disappeared" from the foothills of the Carpathian Mountains, which were reduced to rubble as they were almost entirely made up of wooden houses (Kováč: 176). After the Russian troops had left, the Rusyn population returned back to their devastated and burnt out villages. Because men in the most productive age were conscripted into the army, it was mostly women, children and elderly men who came back. Military mobilization of the most productive workforce showed poverty and a tragic nature of this region even more.

The forced requisitions carried out either by official local authorities or Russian forces sparked an outrage during the war.

People were forced to hand in every horse and supply the army with foodstuff. 192 bells were requisitioned from many Greek Catholic churches. The most valuable bells dated back to the 17 th century 
((Dubová - year 1623 a 1654, Jedlová - 1642, Jastreb - 1645, Soboš 1649 , Borov 1651, Čičava - 1654). The heaviest requisitioned bell was a bell from the Cathedral of St. John the Baptist in Prešov and weighed $1500 \mathrm{~kg}$ (other large requisitioned bells: Šumiac - $830 \mathrm{~kg}$, Hostovice 765 kg, Osadné - 587 kg, Prešov - 575 kg, Čierne - 560 kg, Torysky 475 kg, Olšavica - 469 kg, Černina - 450 kg, Slanské Nové Mesto $424 \mathrm{~kg}$, etc.).

From the beginning of the war, prices of all goods and foods started to rise. With every day of bloody battles on the front, the numbers of widows, orphans, mutilated and dependent people increased (Lipták 1998: 55-56). Even the Greek Catholic Eparchy of Prešov was forced to take out a war loan from the state in order to cope with the difficult situation. The Eparchy, or the consecutive parishes received support from the state «project» intended for restoration of villages destroyed in war. More and more individuals applied for the state support, too.

Greek Catholic clergymen and teachers from the most affected areas of the districts of Medzilaborce, Stropkov, Humenné and Snina turned to a Zemplín county office for financial aid. The county office granted the request and 42 priests and 66 teachers were paid the compensation for the damages caused by the Russian invasion in a total sum of 40000 krone. The most affected were the districts of Medzilaborce, where the financial aid was distributed to 19 priests (in a total sum of $11350 \mathrm{~K})$ and 31 teachers ( $9050 \mathrm{~K}$ ), and the district of Snina, where 12 priests $(5550 \mathrm{~K})$ and 19 teachers $(4550 \mathrm{~K})$ received the aid. 9 priests $(4350 \mathrm{~K})$ and 11 teachers $(3400 \mathrm{~K})$ received the compensation in the district of Stropkov and 2 priests $(800 \mathrm{~K})$ and 5 teachers $(1000 \mathrm{~K})$ in the district of Humenné (AGAP Bežná agenda 1917: 4240).

Greek Catholic priests and teachers from other districts addressed similar requests to their consecutive county offices too, and not only in 1915 but also in the following years. The most requests came in the second half of the year 1917 and then in 1918, the last year of the war (AGAP Bežná agenda 1917: 4240).

Many Greek Catholic churches and parish buildings were damaged, or more or less destroyed during the military operations. As the individual parishes did not have sufficient financial resources to repair these church buildings, they turned with their requests directly to the Bishop's office in Prešov (AGAP Bežná agenda 1917:1953) or to Šariš and Zemplín county offices (Štátny archív v Prešove 1917: 5226) because the eparchy did not have the necessary funds at their disposal either.

In 1915, two independent reports were compiled including date about the damaged church buildings (mainly churches and parish houses), amount of damages, and estimate of the funds needed for their repair. 
Both reports were considerably undervalued, most likely to minimise possible future claims from the villages, or parishes to the state. A report compiled by the State Building Authority of Šariš county divided the sacral objects into four main categories. The first three categories included only Greek Catholic churches and parish houses, objects of other Churches were included in the fourth group.

In the first group, we can find the objects that were destroyed completely (no distinction was made into whether they were destroyed by own or the Russian army; such as churches in the following parishes: Nižná Pisaná /Alsóhimes/, Nižná Polianka /Alsópagony/,Vyšná Polianka /Felso Pagony/, Nižný Komárnik /Alsókomárnok/, Vyšný Komárnik / Felsókomárnok/, Kurimka /Kiskurima/,Nižný Mirošov/Alsómerse/ alebo Hutka /Hutás/). The second group included all the buildings that were extensively damaged and had to be demolished either for safety reasons or because they could not be repaired. Third, and the biggest group was made up of churches damaged only partially. Every entry of this report (every church, parish house and farm building) also contained estimated total repair costs (Štátny archív v Prešove 1915: 112).

\begin{tabular}{|c|c|c|c|c|c|c|c|}
\hline № & Village & $\begin{array}{l}\text { Sum for } \\
\text { a church } \\
\text { repair (K) }\end{array}$ & $\begin{array}{l}\text { Sum for } \\
\text { a parish } \\
\text { house } \\
\text { repair (K) }\end{array}$ & № & village & $\begin{array}{l}\text { Sum for } \\
\text { a church } \\
\text { repair (K) }\end{array}$ & $\begin{array}{c}\text { Sum for } \\
\text { parish } \\
\text { house } \\
\text { repair (K) }\end{array}$ \\
\hline 1 & Andrejová & 170 & 2090 & 20 & Nižný Svidník & 180 & - \\
\hline 2 & Becherov & 160 & 11480 & 21 & Ondavka & 190 & - \\
\hline 3 & Bodružal & 460 & 5960 & 22 & Pstrina & 830 & - \\
\hline 4 & Cernina & 670 & 2690 & 23 & Regetovka & 300 & - \\
\hline 5 & Cigl'a & 400 & - & 24 & Roztoky & 40 & - \\
\hline 6 & Čirč & 700 & 2920 & 25 & Stebník & 11000 & - \\
\hline 7 & Hrabovčík & 17 & 3470 & 26 & Stročín & 7600 & 9500 \\
\hline 8 & Chmel'ová & 1010 & 4380 & 27 & Šarišský Štiavnik & 90 & 2620 \\
\hline 9 & Jurková Vol’a & 7900 & - & 28 & Šemetkovce & - & 1600 \\
\hline 10 & Kečkovce & 550 & 4320 & 29 & Vápeník & 370 & 9200 \\
\hline 11 & Krajná Bystrá & 460 & 6440 & 30 & Varadka & 5600 & 14100 \\
\hline 12 & Krajna Porúbka & 290 & - & 31 & Vyškovce & 280 & 490 \\
\hline 13 & Kružlová & 30 & 3430 & 32 & Vyšná Jedl'ová & 140 & 5670 \\
\hline 14 & Ladomírová & - & 19490 & 33 & Vyšná Písaná & 3000 & - \\
\hline 15 & Medvedzie & 480 & 2600 & 34 & Vyšná Polianka & 9000 & - \\
\hline 16 & Mlynárovce & 1350 & 3900 & 35 & Vyšný Mirošov & 520 & 4210 \\
\hline 17 & Niklová & 770 & 1830 & 36 & Vyšný Orlík & 4300 & 13410 \\
\hline 18 & Nižná Písaná & 860 & 20500 & 37 & Vyšný Svidník & 1400 & 13100 \\
\hline 19 & Nižný Mirošov & 1200 & - & & & & \\
\hline \multicolumn{6}{|c|}{ Total } & 62317 & 169400 \\
\hline
\end{tabular}


$* * *$

By the end of the $19^{\text {th }}$ century there were hardly any Rusyn cultural organizations and there were no publications or newspapers printed in the Prešov region. Only two educational institutions were founded here - the Greek Catholic Theological Seminary (1880) and the Teacher's Seminary (1895), although from the beginning the language of instruction used in both of the institutions was Hungarian (Šturák 1999: 32 -33). The established educational system promoting the one and only, Hungarian language prevented development of new leading figures of Rusyn national revival. It also prevented building and development of national consciousness in the masses of Rusyn nationality (Magocsi 1994: 146). Rusyns started to publish their first magazine in the Prešov region Naše otecsesztvo in 1916. This cultural weekly (published in Prešov in the years 1916-1918) was written in Rusyn, but in the Latin alphabet with Hungarian transcription. Apart from fostering the Greek Catholic faith, the purpose of the weekly was mostly to encourage the faithful in their love for the Hungarian Kingdom (Magocsi 1994: 150).

In keeping with the official magyarization policy, the Hungarian government directly interfered in a management of Greek Catholic eparchies. In 1915, the "Central Committee for Byzantine Catholic Eparchies" was established in order to help maintain, monitor and coordinate their official policy in all Greek Catholic eparchies in Hungarian Kingdom. The founding meeting took place on 27 May 1915. On that day, all Hungarian Greek Catholic bishops were invited by the Ministry of Culture and Public Education in Budapest "to discuss the defence of Greek Catholic faith and nationhood" (AGAP Prezidiálne spisy 1915: 4; AGAP Bežná agenda 1915: 704).

Primate of Hungary and Archbishop of Esztergom János Csernoch was appointed a chairman of the Committee and he also presided its meetings. A representative of the Hungarian government - the Secretary of the Ministry of Culture and Public Education, became a vice-chairman, and the Prešov, Mukachevo a Hajdúdorog eparchies had their representatives in respective subcommittees (four members for each eparchy approved by the primate).

The Central Committee eventually agreed to adopt these principal reforms:

- reform of liturgical ceremonies;

- adoption of the Gregorian calendar;

- abolition of Cyrillic alphabet;

- education reform of young priests in seminaries;

- reformation of the Order of Saint Basil the Great (Lacko 1982: 15). 
One of the reforms that was met with great disapproval by the Rusyn faithful was the reform of script, that is the change of Cyrillic alphabet (azbuka) to Latin. Bishop Štefan Novák of Prešov Eparchy contributed significantly to the elimination of Cyrillic from practice, especially from schools and its replacement by Latin with Hungarian phonetics.

The Hungarian government made sure that this process was under a constant supervision, especially from the Ministry of Culture and Public Education (extensive correspondence between the two institutions). The Hungarian prime minister sent several official letters to the Prešov bishop concerning the Greek Catholic population, their education and a new concept in educating them, as early as the end of 1914. In these official letters, the prime minister wanted to specify the language education and cultural development of the Greek Catholics. The main objective was to eliminate the Cyrillic alphabet from the practice which would "prevent any possible propaganda from the hostile Russia which could result in Rusyns seceding from their home country - Hungary"(AGAP Prezidiálne spisy 1915: 2). Bishop Štefan Novák went along with this proposal and in order for the process to be put into practice, he proposed to publish new Catechism and the Holy Scripture in shortest time possible, because "it would not be possible to eliminate the Cyrillic without publishing these books printed in Latin script and without religious education in mother tongue" (AGAP Prezidiálne spisy 1915: 2).

On 9 August 1915, the Central Committee for Byzatine Catholic eparchies issued an order for the Greek Catholic bishops to implement Latin script into all church elementary schools from the school year of 1915-1916. The Ministry of Culture and Public Education took this matter even further and ordered bishop Štefan Novák to arrange that the Cyrillic would be "eliminated" not only from textbooks, but also from prayer books (AGAP Prezidiálne spisy 1915: 5). Bishop of Esztergom and the primate of Hungary established a special committee for that purpose. The committee was to prepare publishing of liturgical books for the Greek Catholic Church in Latin script (AGAP Prezidiálne spisy 1915:10). The bishop was to follow the guidelines that the Ministry had already sent to him on 1 July 1915 - the guidelines concerned a character and phonetic transcription of Cyrillic into Hungarian alphabet, previously approved by members of the committee (AGAP Prezidiálne spisy 1915: 12). Bishop Štefan Novák took this order into account and ordered to print it out (Slovenský denník 1915: 4; Slovenské l'udové noviny 1915: 3).

Although the majority of Church hierarchy and Greek Catholic priests had already been strongly magyarized, there were still some priests and schoolmasters who did not follow this order. That was the reason why the head of Šariš county sent a letter to bishop Štefan Novák in which 
he urged him to push for the change of script among his clergymen. In his letter the head of county states that the elimination of Cyrillic followed by proper patriotic education will help to increase patriotic consciousness. Elimination of "Russian alphabet" will then protect the faithful from harmful Slavic ideas (e.g. in schools various commemorations of Saints Cyril and Methodius, Saint Basil the Great or other Eastern saints were forbidden, among other things). He concludes that this goal will not be achieved unless the Greek Catholic Church cooperates with the state authorities (AGAP Prezidiálne spisy 1916: 33).

In his letter to a minister of trade, baron János Harkányi, concerning the usage of Rusyn language of instruction in church schools, bishop Štefan Novák reminds the minister a known fact that: "in schools of my eparchy I have ordered teaching in Rusyn language based on written Hungarian phonetics. For that reason it is necessary to rewrite the currently used textbooks or to have the new books printed" (AGAP Prezidiálne spisy 1916: 2). The following books in Rusyn language, but written in Latin script were to be gradually published: Šlabikár s čítankou pre III ročník (Primer with a reading-book for Year III), Obrázkový katechizmus pre III-V ročník (s prípadným liturgickým doplnkom) (The Catechism in Pictures for Year III-V (with possible liturgical supplement)), Obrázková biblia pre III-V ročník (The Bible in Pictures for Year III-V), Malý modlitebník pre IV-VI ročník (Little prayer book for Year IV-VI), Čítanka pre IV-V ročník (Reading-book for Year IV-V), Zborník pre dospelých (spevník a modlitebník zozbieraných a aj liturgických modlitieb) (Anthology for Adults (hymnbook and prayer book of collected and liturgical prayers)), Denník a ludový kalendár (Daily and calendar) (Székely 2004: 35-36).

From the above mentioned textbooks only "Šlabikár s čítankou pre III. ročník" (Primer with a reading-book for Year III) and "Čítanka pre IVV ročník" (Reading-book for Year IV-V) were published in the end. Both books followed the characters of Hungarian phonetics. The former was composed of two-thirds of various readings and one-third of alphabet recognition. The latter contained sections selected from Rusyn books and sections from Hungarian translations. Minister of Culture and Public Education Dr Béla Jankovich showed a personal interest in these books and prior to their publications he sent a letter to bishop Štefan Novák informing him about his position.

Particularly interesting is the closing part of the letter which reads: "Readings with religious connotation can naturally be acceptable, especially if it meant breaking away from the idea of Pan-Slavism. Poetical works of foreign Slavs are absolutely undesirable, works of local Slavic poets are acceptable provided that they are flawless from the national 
standpoint or irreplaceable for their artistic value. Acceptable are also simple works of Rusyn poetry" (AGAP Prezidiálne spisy 1915: 13).

There were also other textbooks considered for publication but their final publishing and distribution was halted by several circumstances related to the war events of the First World War.

To endorse the policy of magyarization, the Hungarian government decided to print a newspaper and calendar for the Greek Catholic faithful but in Latin script. Prešov bishop Štefan Novák endorsed this initiative. He sent a letter to the prime minister István Tisza in which he notes that «omission of commonly used Cyrillic would weaken and exclude the Russian influence on our faithful and thus prevent our people from abandoning the union with Rome. It can also boost Hungarian patriotism from the religious and moral point of view» (AGAP Prezidiálne spisy 1915: 1). In January 1916 a new Greek Catholic cultural weekly Naše otecsesztvo was founded (published in Prešov in the years 1916-1918). It was written in Rusyn, but in the Latin alphabet with Hungarian transcription. Apart from fostering the Greek Catholic faith, the purpose of the weekly was mostly to encourage the faithful in their love for the Hungarian state.

Proposals put forward by the Hungarian government (through Archbishop of Esztergom and the Central Committee for Byzantine Catholic Eparchies) concerning the publication of new liturgical books were perceived as an interference in Eastern tradition of Greek Catholic Church. János Csernoch, Archbishop of Esztergom and primate of Hungary, notified Štefan Novák in an official letter that the Central Committee was going to republish texts of liturgical books in Church Slavonic. It concerned five books: "Liturgikon" (book of divine services), "Evanjelium" (the Gospel), "Apoštol" (Apostle (Acts of the Apostles and letters of St. Peter, Paul and Jacob)), "Euchologion" (Trebnik - service book) and "Oktoich" (osmohlasnik - contains changeable portions of canonical hours for a day of a week cycle) (AGAP Prezidiálne spisy 1915: 26).

The Central Committee raised also numerous objections concerning primarily the Byzantine-Slavic Church tradition. Namely they were various terminological objections (to replace words such as Carja, sobornaja, pravoslávnyj, russkaja vira, etc. with other words), or objections to paying respect to some of the Eastern Saints who were venerated by the Orthodox Church, too (e.g. St. Anton, St. Paraskiev, St. Boris and Gleb, St. Vladimir, St. Ol'ga or St. Gregory Palamas). Feast of the Protection of the Most Holy Mother of God was also unacceptable because it was considered far to pro-Russian by the Hungarian authorities. That is why the government requested to change the lyrics of songs which were sung during this holiday. They apparently insulted the national 
consciousness of Magyars in Hungary. Celebration of Saints Cyril and Methodius was also deemed unacceptable because "it could grow into Slavic national holiday, which in fact is not necessary within the Hungarian territory"(AGAP Prezidiálne spisy 1915: 14-15).

Such "unsuitable" holidays were to be soon replaced by different holidays commemorating adherents of the Arpad family or some other prominent Hungarian saints (AGAP Prezidiálne spisy 1915: 30).

Adoption of the liturgical calendar reform, that is a change from the Julian to Gregorian calendar brought mostly negative feelings in the Greek Catholic Church (mainly in the Eparchy of Mukachevo and largely in the Eparchy of Prešov, too).

This proposal was approved on 9 August 1915 by the Central Committee of Byzantine Catholic Eparchies. The chairman of the Committee, Archbishop of Esztergom János Csernoch informed Greek Catholic bishops, Štefan Novák of Prešov (AGAP Prezidiálne spisy 1915: 25), Anton Papp of Mukachevo and Štefan Miklósy of Hajdúdorog and asked them to take a stand on this issue. Bishops of Prešov and Hajdúdorog replied in favour for the calendar reform. In Hajdúdorog, the clergy took a positive stand too, whereas in the Eparchy of Prešov neither clergy nor the faithful followed the example of their bishop and majority opposed the change. In the Eparchy of Mukachevo, bishop, clergy and the faithful collectively rejected the reform. On 22 June 1915, the officials of the Eparchy of Mukachevo prepared a memorandum in which they protested against the proposed change of the calendar even before it was approved. Then they delivered the memorandum to the apostolic nuncio in Vienna. After reviewing all facts, the nuncio agreed with the claims of memorandum and exercising his rights, he vetoed the government's decision. The reform had to be abandoned for some time (Lacko 1982: 15).

Although the reaction of the Eparchy of Prešov to the calendar reform was largely rejecting (AGAP Prezidiálne spisy 1916: 33), priests in some of the deaneries supported it. For instance, priests of Cserhát deanery, demanded the implementation of the reform. On 14 November 1915 they sent a letter to bishop Novák requesting him to follow an example of the Eparchy of Hajdúdorog (where the calendar reform was already implemented in autumn 1915) and make an agreement with the bishop of Mukachevo and adopt the reform.

On 4 May 1916 the Central Committee of Byzantine Catholic Eparchies held another round of talks in Nyiregyháza where the definite calendar reform was decided. The Committee informed the Apostolic nunciature in Vienna as well as the imperial court about the results (AGAP Prezidiálne spisy 1916: 34). Greek Catholic bishops also notified the prime minis- 
ter. In the joint letter they expressed hope for the influential support from legislative bodies, should they need some. Since the unification of calendars had not been previously consulted with either the Holy See or the faithful, the bishops pleaded with the prime minister to support their intention through diplomatic channels, should the Holy See take an opposing stance (AGAP Vária 1910-1924: 949).

The most appropriate time for the change of the calendar came in 1916 when the Easter, the determining "date" of liturgical calendar, was celebrated on the same day according to the "old" and the "new" calendar. The Hungarian government, though, did not wait for the opinion of Rome and ordered the bishops of Mukachevo, Hajdúdorog and Prešov to implement the Gregorian calendar in their eparchies on 24 June 1916 (Nativity of Saint John the Baptist) (AGAP Bežná agenda 1916: 730). The official proclamation of the new calendar came after the release of a joint pastoral letter of the three bishops (letter was published in the newspaper Magyar Kurir on 23 May 1916). In the newspaper the bishops explained the scientifically verified inaccuracy of the Julian calendar and stated that its usage is "untenable on cultural level" which could result in Greek Catholics lagging behind in social area. The main drawback was asynchronism in celebration of holidays in comparison to the faithful of Latin rite. There was some degree of isolation that showed mainly in social and economic sphere of the Greek Catholics. The everyday reality, bishops claimed, for more and more Greek Catholics was loss of faith in their rite due to inconvenience of the Julian calendar. Therefore they decided to express their mutual opinion that "the Julian calendar does not represent an organic creative part that is in any way uplifting for the Greek Catholic rite and therefore any further usage of this calendar is unjustified. It is then advised to abandon the calendar for the sake of preserving loyalty to the Greek Catholic rite and for the better understanding of good and progress" (AGAP Vária 1910-1924; Magyar Kurir 1916: 1-2).

When introducing the calendar change, bishop Štefan Novák collaborated with the heads of respective counties who often used the state apparatus to repress any protests. Resistance of the faithful in the eparchies of Prešov and Mukachevo to the state order manifested itself in 1917. People had to be forced to celebrate Easter holiday according to the new calendar (the Easter Sunday fell on 8 April in 1917) by he police (Birčak 1938: 154-155). Similar situation repeated the following year (31 March 1918). The situation gave rise to several movements of Greek Catholics who were protesting against the transition to the Gregorian calendar. Many organisers of these movements were then subjected to criminal prosecution and some of the members were arrested (AGAP Bežná agenda 1918: 1095). 
To calm the situation in his eparchy in early November 1918, bishop Štefan Novák ordered to use the Gregorian calendar as an option. According to this order, some kinds of plebiscites were held in the parishes in November and December 1918. The faithful were to decide either for the new calendar or the old one. The absolute majority of parishes in the Eparchy of Prešov rejected the new calendar and requested return to the Julian calendar.

Another interesting thing is worthy of notice in relation to these reports. The huge majority of them were recorded in Hungarian language despite the fact that the independence of the Czechoslovak republic had been proclaimed a month before (AGAP Vária 1910-1924; AGAP Bežná agenda 1918: 4122).

Return to the old calendar was carried out in the heart of the eparchy, in Prešov on 7 December 1918. Vicar General Mikuláš Russnák ordered to serve Vesper (večiereň) from 24 November and from the previous VII. ordinary tone on 8 December (AGAP Vária; Székely 2004: 55).

The end of the First World War meant that the Hungarian government did not have enough time to implement the reforms so that they became established. After the dissolution of Austro-Hungary in 1918, the faithful in a successor state of Czechoslovakia (Eparchies of Prešov and Mukachevo) decided to keep the old Julian calendar and Cyrillic script. In Hungary (the Eparchy of Hajdúdorog and since 1923 also in the newly established Apostolic Exarchate in Miskolc) the faithful opted for the Gregorian calendar and Latin script. Moreover, besides Church Slavonic, Hungarian language became another official liturgical language there.

\section{$* * *$}

Following the end of the First World War in November 1918 and subsequent fall of the Habsburg empire, the Slavic nationalities of the former Austro-Hungarian empire began to form their own national councils that were to decide their future. Rusyn politicians, represented mainly by emigrants residing in the USA and by Rusyns living in the Carpathian region supported either the idea of independent Rusyn state, or fully autonomous Rusyn state within larger unspecified state. Newly established government of the post-war Hungarian republic was informed about these Rusyn claims. In an effort to maintain the Rusyn territory within the borders of their state, Hungary established autonomous region Ruská Krajina with an administrative seat in Mukachevo in December 1918 (Magocsi 1999). At the same time (November 1918 - January 1919) Rusyn political leaders kept meeting in their councils endorsing union either with Hungary, Russia, Ukraine 
or Czechoslovakia. In May 1919, the Central Rusyn National Council "Central'na rus'ka narodna rada" in Uzhhorod decided that Rusyns, inhabiting territories south of the Carpathian Mountains, would join with Czechs and Slovaks. New Czechoslovak state brought a slight improvement for Rusyns and their status in Slovakia. On the other hand, certain hopes of this nation were dashed again. Despite the original plans for federal system of government, the state adopted a centralist model with the main political and cultural centre in Prague. The question of Rusyn autonomy, which Czechoslovakia embedded in the Constitution from 29 February 1920 but never brought into effect, has become a priority in all political activities of Rusyn politicians.

\section{REFERENCES}

Archive of Greek Catholic archbishop in Presov (AGAP). (1915) Fund: Bežná agenda. Inventory number 431. Signature 704.

Archive of Greek Catholic archbishop in Presov (AGAP). (1916) Fund: Bežná agenda. Inventory number 432. Signature 704.

Archive of Greek Catholic archbishop in Presov (AGAP). (1917a) Fund: Bežná agenda. Inventory number 433. Signature 1953.

Archive of Greek Catholic archbishop in Presov (AGAP). (1917b) Fund: Bežná agenda. Inventory number 433 . Signature 4240.

Archive of Greek Catholic archbishop in Presov (AGAP). (1918a) Fund: Bežná agenda. Inventory number 434. Signature 1095.

Archive of Greek Catholic archbishop in Presov (AGAP). (1918b) Fund: Bežná agenda. Inventory number 434 . Signature 4122.

Archive of Greek Catholic archbishop in Presov (AGAP). (1915a) Fund: Prezidiálne spisy. Inventory number 58. Signature 1.

Archive of Greek Catholic archbishop in Presov (AGAP). (1915b) Fund: Prezidiálne spisy. Inventory number 58 . Signature 2.

Archive of Greek Catholic archbishop in Presov (AGAP). (1915c) Fund: Prezidiálne spisy. Inventory number 58 . Signature 4.

Archive of Greek Catholic archbishop in Presov (AGAP). (1915d) Fund: Prezidiálne spisy. Inventory number 58 . Signature 5 .

Archive of Greek Catholic archbishop in Presov (AGAP). (1915e) Fund: Prezidiálne spisy. Inventory number 58. Signature 10.

Archive of Greek Catholic archbishop in Presov (AGAP). (1915f) Fund: Prezidiálne spisy. Inventory number 58. Signature 12.

Archive of Greek Catholic archbishop in Presov (AGAP). (1915g) Fund: Prezidiálne spisy. Inventory number 58. Signature 13.

Archive of Greek Catholic archbishop in Presov (AGAP). (1915h) Fund: Prezidiálne spisy. Inventory number 58. Signature 25. 
Archive of Greek Catholic archbishop in Presov (AGAP). (1915i) Fund: Prezidiálne spisy. Inventory number 58. Signature 14-15.

Archive of Greek Catholic archbishop in Presov (AGAP). (1915j) Fund: Prezidiálne spisy. Inventory number 58. Signature 30.

Archive of Greek Catholic archbishop in Presov (AGAP). (1916a) Fund: Prezidiálne spisy. Inventory number 59. Signature 2.

Archive of Greek Catholic archbishop in Presov (AGAP).(1916b) Fund: Prezidiálne spisy. Inventory number 59. Signature 33.

Archive of Greek Catholic archbishop in Presov (AGAP). (1916c) Fund: Prezidiálne spisy. Inventory number 59. Signature 34.

Archive of Greek Catholic archbishop in Presov (AGAP). (1910-1924) Fund: Vária - obežníky, Pastierske listy, reči. Inventory number 1275. Signature 1-3.

The State Archive in Presov. (1915) Fund: Šarišská župa - hlavný župan. Inventory number 173/1915.112.

The State Archive in Presov. (1917) Fund: Šarišská župa - hlavný župan. Inventory number 175/1917. Signature 4665, 5256.

Birčak, A. (1938) Na Novych Zemlach [On New Lands]. Lviv. pp. 154-155.

Bural', M. (2010) Osem dni, ktoré otriasli Uhorskom. Zabudnuté 95. výročie bojov prvej svetovej vojny o Sninu [Eight days that shocked Hungary. The Forgotten 95th Anniversary of the Battles of World War I for Snina]. Naša Snina. 10. p.11-12.

Kováč, D. et al. (2008) Prvá svetová vojna 1914 - 1918 [World War I of 19141918]. Bratislava: Veda.

Lacko, M. (1982) Z našej minulosti: Biskup Anton Papp [From Our History: Bishop Anton Papp]. Mária č. 6. p. 15.

Lipták, L'. (1998) Slovensko v 20. storočí [Slovakia in the 20th century]. Bratislava: Kalligram.

Magocsi, P.R. (2007) Národ znikadial' [The nation from nowhere]. Prešov: Rusín a L'udové noviny.

Magocsi, P.R. (1994) Rusíni na Slovensku [The Rusyns in Slovakia]. Prešov: Rusínska obroda.

Magocsi, P.R. (1999) Mapovanie národov bez štátu: východní Slovania $\checkmark$ Karpatoch [Mapping the stateless nations: Eastern Slavs in the Carpathian Mountains]. Čas a spoločnost' - The Time and Society]. 2(2).

Magyar Kurir. (1916) 6(2). pp. 1-2.

Slovenský denník. (1915) 6, 29. 9.

Slovenské l'udové noviny. (1915) 6,1.10.

Národnie noviny. (1921) 52,19.10. n. 236.

Slepcov, I. (2005) Prvá svetová vojna na východnom Slovensku v rokoch 1914-1915 [World War I in Eastern Slovakia in 1914-1915]. In: Mikita, M. (ed.) Prvá svetová vojna. Pozabudnuté cintoríny [World War I. The Forgotten Cemeteries]. Svidník: Regionálna rozvojová agentúra Svidník. p. 20. 
Székely, P. (2004) Biskup Dr. Štefan Novák (život a dielo) [Bishop Dr. Stefan Novak (Life and Work)]. Prešov: GTF PU.

Šturák, P. (1999) Dejiny gréckokatolíckej cirkvi v Československu v rokoch 1945 - 1989. [The History of the Greek Catholic Church in Czechoslovakia in 1945-1989]. Prešov: Petra.

Цоранич Ярослав - кандидат философских наук, доцент, заведующий кафедрой исторических наук греко-католического теологического факультета Прешовского университета, заместитель декана греко-католического теологического факультета по образованию и аккредитации.

Coranič Jaroslav - University of Prešov (Slovak Republic).

E-mail: jaroslav.coranic@unipo.sk 